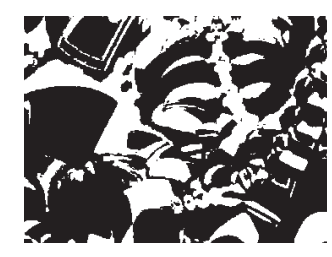

\title{
DESTINATION BRANDING OF EUROPEAN RUSSIA: AN EMPIRICAL INVESTIGATION OF THE WEB PROJECTED IMAGERY
}

Tanja ARMENSKI, Uglieša STANKOV

Faculty of Sciences, University of Novi Sad, Novi Sad

Hwan-Suk $\mathrm{CHOI}$

School of Hospitality, Food and Tourism Management, University of Guelph, Guelph, ON, Canada

UDK: $338.487(470): 659.1-028.27$ $338.48-4(470)$

Izvorni znanstveni rad

Primljeno: 8. 9. 2016.

Web branding is an important strategic tool for building a promising travel experience that is uniquely associated with the destination and that reinforces the emotional connection between the visitor and the place. With the proliferation of the Internet, destination marketing organizations' (DMO) websites became a crucial communication channel for projecting a desirable place brand image. With an attempt to rehabilitate the brand image of Russia, this study explores the following: (1) What are dominant attributes in the brand images of European Russia communicated via the DMO websites? (2) Which words appear most frequently on the DMO websites of European districts of Russia? (3) Is there a discrepancy between the projected brand images and stories it tells in words on the DMO websites? As these perspectives contribute to a better understanding of the induced component of Russia's destination brand image in the online environment, content analysis of DMO websites from three European Russian regions is conducted and practical implications are discussed. The results have important marketing implications.

Keywords: place branding, brand images, DMO websites, European Russia

Tanja Armenski, Department of Geography, Tourism and Hotel Management, Faculty of Sciences, University of Novi Sad, Trg Dositeja Obradovića 3, 21000 Novi Sad, Serbia. E mail: tanja.armenski@dgth.uns.ac.rs 
In the past three decades, Russia has undergone extensive changes in its political, economic, and social spheres that have had a greater effect on the national image of the country (Simons, 2011). Specific challenges facing Russia include the negative image of the Soviet past and associations that tend to reinforce the symbols of stereotypical culture and aggression (Dinnie, 2008; Roberts, 2014). It has been argued that Russia needs to invoke a new vision of itself as a forward-looking nation (Simons, 2011). Future Russian destination brand strategies should demonstrate the country's economic transformation, post-industrial thinking, and a new type of communication with the world (Ivanov, 2001). However, regardless of Russia's attempt to influence a more positive global perception of their national symbols, the country seems to be locked between the past and current images (Istomina \& Samoylenko, 2015; Faizova, Kozhevnikova, Kashipova, Zinurova, \& Egorov, 2015; Nikolaeva, Bogoliubova, \& Shirin, 2018).

While national branding is the application of marketing techniques to countries to improve their international images of the nations, destination branding, facilitated by tourism services and tourism experiences, aims at improving brand images of travel places. Branding a place is a policy concern that enables the place to improve the speed, efficiency and effectiveness with which they achieve a better image (Anholt, 2008). As such, this strategic process requires synchronized effort and greater co-operation between tourism businesses, governments, and non-profit organizations to align brand messages and to position DMO to communicate emotionally evoking, exciting, worth-visiting brand images for their travel destinations.

In this instance, destination marketing organizations (DMOs), as their name clearly indicates, play a significant role in place promotion, particularly creating and projecting desirable place brand images. When it comes to the website branding strategies, the effective strategies should enable travelers to associate the symbols with the destination via projected images and ideally create an emotional connection with the destination (Blain, Levy, \& Ritchie, 2005).

With the proliferation of the Internet and e-commerce, websites became the important medium of tourism promotion, especially as a communication channel for projecting desirable place brand images (Költringer \& Dickinger, 2015). As such, since marketing driven, DMOs play a significant role in communicating the desirable brand images of a place via websites. Thus, the DMOs in Russia should effectively use the information and communication technology to serve their branding purposes. By selecting unique symbols, logos, pictures and messages to compose the place brand images, the desti- 
DRUŠ. ISTRAŽ. ZAGREB GOD. 27 (2018), BR. 4, STR. 735-755

ARMENSKI, T., STANKOV, U., $\mathrm{CHOI}, \mathrm{H}-\mathrm{S}$. DESTINATION.. nation can differentiate its brand identity from the competitors (Cai, 2002). These images, as noted by Anholt (2008), are at the same time a component of the national story and the means of telling it. Thus, successful place branding requires DMOs to have clearly and consistently defined brand images that will be visually projected and communicated online.

Particularly for Russia, effective web branding is challenged by large and diverse national elements that need to be framed in a coherent perceptual entity (Dinnie, 2008). Hence, a great coordination between the different state and private sector actors engaged in Russia's nation branding efforts is of prime importance. Over the last decade, academics argue that web projected tourism products are often duplicated in the content-thematic content, and the majority of DMO websites do not offer distinctive tourism services and products that could position them uniquely in the mind of potential travelers (Krivosheeva, Kopylov, \& Tatiana, 2015).

As opposed to competing the global standardized attributes based on Western media-generated expectations, places need to build the brand equity and sustain their competitive advantage (Govers \& Go, 2009). This can be an arduous challenge for countries such as Russia. The largest country in the world still has a problem creating the desirable brand image in the West and, at the same time, had to confront a negative national image that is still being created by constant political disagreements with major Western countries (Stepchenkova \& Morrison, 2008; Saunders, 2016). The first attempt in this challenge is to inspect the current place brand image that is being officially projected. That is the main goal of this paper. This exploratory study focused on the European part of Russia.

This research paper aims at answering the following questions: 1) What are dominant attributes in the brand images of European Russia communicated via the DMO websites? (2) Which words, such as "Moscow", "ancient", appear most frequently on the DMO websites of European districts of Russia? (3) Is there a discrepancy between the projected brand images and stories they tell in words on the DMO websites?

The paper is structured as follows. Section one examines the case of the Russian tourism brand. Engagement of state and private entities in the Russian national branding effort is reviewed. The role of local DMO websites in projected imagery is discussed in detail. Section two explains the research design and data collection procedure. The study findings are presented in section three. The research results are then discussed. The research results are compared between the examined European Russian districts and the projected brand images of the districts are evaluated. In conclusion, the paper addresses the key issues of place branding that require the attention of destination practitioners. 


\section{LITERATURE REVIEW}

\section{Place branding and destination branding}

Branding is used with the term 'destination' when it implies a tourism perspective, while place branding provides a wider perspective that includes all interactions of a place with its environment, such as political, outside investment, trade, immigration and media issues. Both destination branding and place branding could include nation or country, region or city branding (Anholt, 2009).

When conceptualized on the national level, the national brand is perceived as the sum of people's perceptions of a country across several areas of national competence: exports, governance, tourism, investment and immigration, culture and heritage, and people (Anholt, 2005). Gnoth (2002), for instance, argued that the tourism industry is an influencing determinant of the country's image, capable of leveraging a national brand through a tourism destination brand. In this respect, destination branding is a critical component of national brand.

Destination branding can be broadly defined as: "the set of marketing activities that (1) support the creation of a name, symbol, logo, word mark or other graphic that readily identifies and differentiates a destination; that (2) consistently convey the expectation of a memorable travel experience that is uniquely associated with the destination; that (3) serve to consolidate and reinforce the emotional connection between the visitor and the destination; and that (4) reduce consumer search costs and perceived risk (Blain et al., 2005, p. 337). Collectively, these activities serve to create a brand image of a place.

Thus, the core of destination branding is to build a positive destination image that identifies and differentiates the destination by selecting a consistent brand element mix $(\mathrm{Qu}$, Kim, \& Im, 2011; Cai, 2002). The image of a destination brand can be defined as "perceptions about the place as reflected by the associations held in tourist memory" (Cai, 2002, p. 723). As such, destination image is a largely subjective and perceptual phenomenon formed through personal interpretation of these marketing efforts, whether reasoned or emotional (Balakrishnan, Nekhili, \& Lewis, 2011).

At a smaller scale, especially in the case of large countries, separate travel destinations can create different place brand images. Place brand images should make explicit the complexity of experiences to be expected when visiting places (Almeyda-Ibáñez \& George, 2017). As such, place brand image influences not only the choice of destination but also the level of travelers' satisfaction (Költringer \& Dickinger, 2015; Govers \& Go, 2009). 
DRUŠ. ISTRAŽ. ZAGREB GOD. 27 (2018), BR. 4, STR. 735-755

ARMENSKI, T., STANKOV, U., $\mathrm{CHOI}, \mathrm{H}-\mathrm{S}$. DESTINATION...
Although there is general assent that the problem of place branding is well researched (Hankinson, 2009), in the post-modern societies where information and communication technology create a dynamic physical and virtual environment, place branding has changed dramatically from both the supply (projecting of identity) and demand (perceiving of images) perspectives (Govers \& Go, 2009). Namely, the Internet boom, characterized by billions of internet users and much greater number of websites, created a new multi-node network of beacons for projecting different place brand images. It is highly unlikely that they all represent consistent place brands of broader areas (Govers \& Go, 2016). Therefore, little attention has been given to the development of a common framework for place branding which can be replicated yet be effective in utilizing the unique place brand images and, thus, form the basis for its future practical employment.

\section{The role of local DMOs in Web projected imagery}

As increasing numbers of people use the Internet for information search, the World Wide Web has been established as one of the most important communication channels to quickly reach the international travelers and introduce travel destinations. In other words, destination branding via the website has arguably become one of the most important marketing strategies, functioning as the glue that holds the broad range of marketing factions together (Tatevossian, 2008). By reviving visual travel experiences, the Internet overcomes the intangible nature of services and tourism attractiveness offered by the destination (Stepchenkova \& Morisson, 2006).

Destination marketing organization, as its name clearly implies, plays a significant role in projecting a desirable brand image of a place. The DMO websites predominantly focus on brand building and destination promotion by applying emotional appeal embedded within the web communications (Gonzalez \& Bello, 2002). As such, DMOs should seek to produce an instantly recognizable brand identity by projecting "exciting, memorable, dramatic, picturesque, newsworthy, touching, surprising" brand images (Anholt, 2008). These images, as noted by Anholt (2008), should be at the same time a component of the national story and the means of telling it.

Brand images forge the connection between visitors and travel destination, build visitors' loyalty, and determine how visitors will perceive the brand of the destination (Stepchenkova \& Morrison, 2006). Therefore, these projected imageries via DMO websites are the key creators of the traveller's asso- 


\section{The components of images}

Regarding the component of pictorial materials itself, Albers and James (1988) argued that photography has two main components, namely content and composition. According to those authors, content refers to the 'appearances or signs captured in a photo in their totality' while the way in which these 'appearances are linked to each other and presented to viewers constitute the photo's composition.' Furthermore, viewers treat all elements of a photograph as symbols that collectively allude to a meaning that lies outside of a picture. Those symbols should represent emotional qualities of the travel destination verbally and visually in a clear, simple and unique way (Fan, 2006). Effective branding enables travelers to associate those symbols with the destination, ideally creating favorable place brand images and leading to emotional attachment with the place (Blain et al., 2005).

The complex nature of the brand image presents great challenges for its measurement. Stepchenkova, Kirilenko, and Morrison (2009) noted that content analysis of web pictorial material is often attribute-based with the quantitative description of certain themes and appearance attributes in the collection of images. This allows for the main focal themes in the pictures to be identified through frequency co-occurrence, clustering, and other related issues to be recorded.

In addition, when content analysis of pictorial material is accompanied by the textual analysis of a website, researchers usually employ sorting and categorization techniques to classify the frequencies of certain words, concepts, objects, or people, which for ease of further reference are referred to as "meaningful words". The most frequently occurring meaningful words are then treated as image variables or dimensions of the destination image construct (Költringer \& Dickinger, 2015; Stepchenkova \& Morrison, 2006). For example, Govers and Go (2004) used photographic imagery and narratives (textual representations) to analyze the projected identity of Dubai as a travel destination. Their results confirm that local DMOs focus on the projection of cultural identity and heritage, compared to private sector organizations that are orientated toward advertising and booking travel services. Similarly, Choi, Lehto, and Morrison (2007) used both qualitative (text mining and expert judgment) and quantitative approaches (correspondence analysis) to content analyze the narrative and visual information on Macau travel-related websites. Finally, Stepchenkova et al. (2009) argue that such a methodological approach as reliable, yet simple and efficient enough to be used in tourism studies. 
DRUŠ. ISTRAŽ. ZAGREB GOD. 27 (2018), BR. 4 STR. 735-755

ARMENSKI, T., STANKOV, U., $\mathrm{CHOI}, \mathrm{H}-\mathrm{S}$. DESTINATION..
Following the relevant methodological approach described above, this study combines content analysis of pictorial material grasped from the DMO websites of European Russian districts with the text analysis to better understand projected brand attributes of the destination image and the most frequent meaningful words that induce components of Russia's destination brand image in the online environment.

METHODOLOGY

\section{Sample selection}

Firstly, the complete list of the official Russian DMOs by regions was obtained from the official portal of The Federal Agency for Tourism of the Russian Federation. This list was then revised and districts which lack the websites in English language, such as North Caucasian Federal District, Crimean Federal District and South Federal District, were excluded from further analysis. The districts with the representative number of websites in English language were kept. In total, $21 \mathrm{DMO}$ websites were analyzed representing Central Federal District (8), Northwestern Federal District (7), and Volga Federal District (6). According to the Federal Agency for Tourism (2016), these districts facilitate a sizable portion of accommodation capacity and host many domestic and international travelers.

\section{Data collection and analysis}

Two research approaches were used. First, content analysis was conducted to reveal the most frequently used attributes in the pictorial materials of European Russia projected via official DMO websites. Content analysis was used to "systematically evaluate the symbolic content of all forms of recorded communications" as a preliminary analysis (Kolbe \& Burnett, 1991, p. 243). Graphic images projected on the front page of each website were chosen and the content analysis of branding elements in the pictorial material was explored. Projected images were mainly related to the country's geography, history, proclamations, culture and other unique national features. The content analysis of pictorial material presented on the official DMO websites was inspired by the work of Stepchenkova and Zhan (2013) who provided the theoretical grounding for thematic categorization of pictorial attributes.

Following their work, a total of 20 categories were used to describe the brand images projected via DMO websites. Although in the study of Stepchenkova and Zhan (2013) churches and monasteries were classified under "Architecture/Buildings", in the present study "Churches and Monasteries" were counted as a separate category, due to frequent occurrence in the web projected pictures. 
DRUŠ. ISTRAŽ. ZAGREB GOD. 27 (2018), BR. 4 STR. 735-755

ARMENSKI, T., STANKOV, U., $\mathrm{CHOI}, \mathrm{H}-\mathrm{S}$.: DESTINATION.
Each photo that appeared on the front page of a DMO website was treated as a single unit of content and assigned to only one category, in contrast to Stepchenkova and Zhan's (2013) approach, which classifies images in up to four categories. This process significantly reduces the complexity of photographic materials, as it is subjective, i. e. based on the researchers' perspective. Therefore, the authors had to agree on the main category of every single unit to reduce the bias of personal perspective.

After data categorization, the chi-square test (Appendix 1) and the co-occurring analysis were conducted. The chi-square test measures the independence of the total attribute counts between the districts. The co-occurring analysis unravels the pattern and the probability of attributes that co-occurred on the websites of the examined districts. Co-occurrence analysis stems from ecological sciences for detecting the probability and frequency of pairs of species that share certain sites, and it is available in the R package "cooccur". The analysis is broadly used for examining species coexistence, community structure and species assembly (Griffith, Veech, \& Marsh, 2016). In our case, categorized attributes (Appendix 1) were treated as species (rows) and districts were treated as sites (columns). Attributes in the pictorial material were presented in the binary presence-absence matrix.

Second, to support the exploration of brand images projected via DMO websites, this research includes an examination of the meaningful words from the selected websites with advanced web content mining. Text content was scraped from the DMOs' home webpages and 1st level webpages, including the major sections from the website navigation on a homepage. The text files are analyzed for word frequencies by using the Atlas.ti v7 software for qualitative analysis of large bodies of textual materials. This research technique allows for extraction of the most frequently used words in the texts that appear on the web pages (Bharanipriya \& Prasad, 2011; Liu, 2007). This procedure automatically discovers the word patterns and extracts meaningful information, such as destination descriptions or user sentiment.

In total 100,188 words were collected, but only words with frequencies of $0.05 \%$ or higher are kept for further analysis. To keep it clear, but comprehensive, extracted words were grouped as follows: the core-value (such as festivals, cities, crafts, etc.), the toponyms (clearly representing the core-value promoted), the descriptive words (ancient, famous, etc.) and the functional words (words holding semantic basis such as tourists, visit, region, history, century, etc.). 


\section{RESEARCH RESULTS}

\section{Attribute test of independency and co-occurrences analysis}

Central Federal District

In the Central Federal District, the most frequent attributes are Art Object, which includes folk art, museum art, and modern art reflecting Russian ancient or modern culture. Close-ups of arts and crafts produced by local people are also included in Art Object. Churches and Monasteries are separately presented as dominant symbols in the CF district. Festivals and Rituals, which include both traditional and modern events are significant attributes on the DMO CFD websites. The Architecture/Buildings category refers to both the interior and exterior of buildings and architecture in urban and rural areas, and this attribute is relatively frequent in the projects' pictorial material in the CFD. Interestingly, Nature \& Landscape, which includes natural formation and water bodies, such as mountains, deserts, forests, jungles, rivers and lakes, seas, caves, and the like, as well as the Country Landscape, are not dominant attributes of the CF district. Surprisingly, people, the way of local life, tourism, and outdoor facilities are not on the perceptual map of the DMO CFD. Such images should engage potential travelers with favorable travel experiences and tourism adventures. In general, pictorial material

(1) FIGURE 1 projected on the DMO CFD websites leaves an impression of Central Federal District image frequency passive scenery which lacks the symbols that could involve potential travelers emotionally (Figure 1).

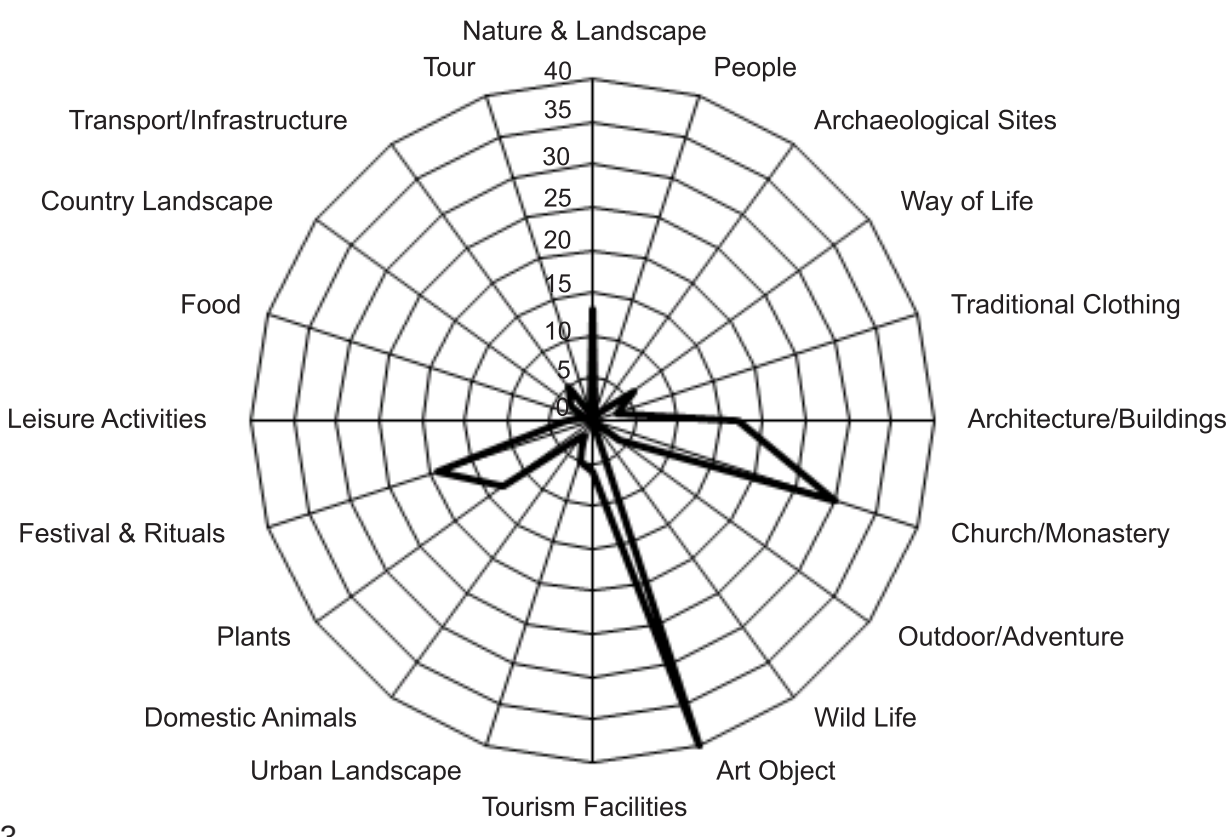


DRUŠ, ISTRAŽ. ZAGREB GOD. 27 (2018), BR. 4 STR. $735-755$

ARMENSKI, T., STANKOV, U., $\mathrm{CHOI}, \mathrm{H}-\mathrm{S}$.: DESTINATION.

(1) FIGURE 2

Northwestern Federal District image frequency

\section{Northwestern Federal District}

Dominant attributes of the NFD are Festivals and Rituals and Nature and Landscape. Festivals and Rituals are associated with the local events and entertainment. These pictures frequently depict individuals in a happy mood who are enjoying both modern and traditional music and dance. Apart from that, Churches and Monasteries, Art Objects and Architecture \& Buildings are dominant attributes. Similarly to other districts, there is a lack of attributes associated with the local people's way of life, food, tourism, and outdoor tourist facilities offered by the destination/district. The pictorial attribute occurrences on the DMO websites in the NFD are shown in Figure 2.

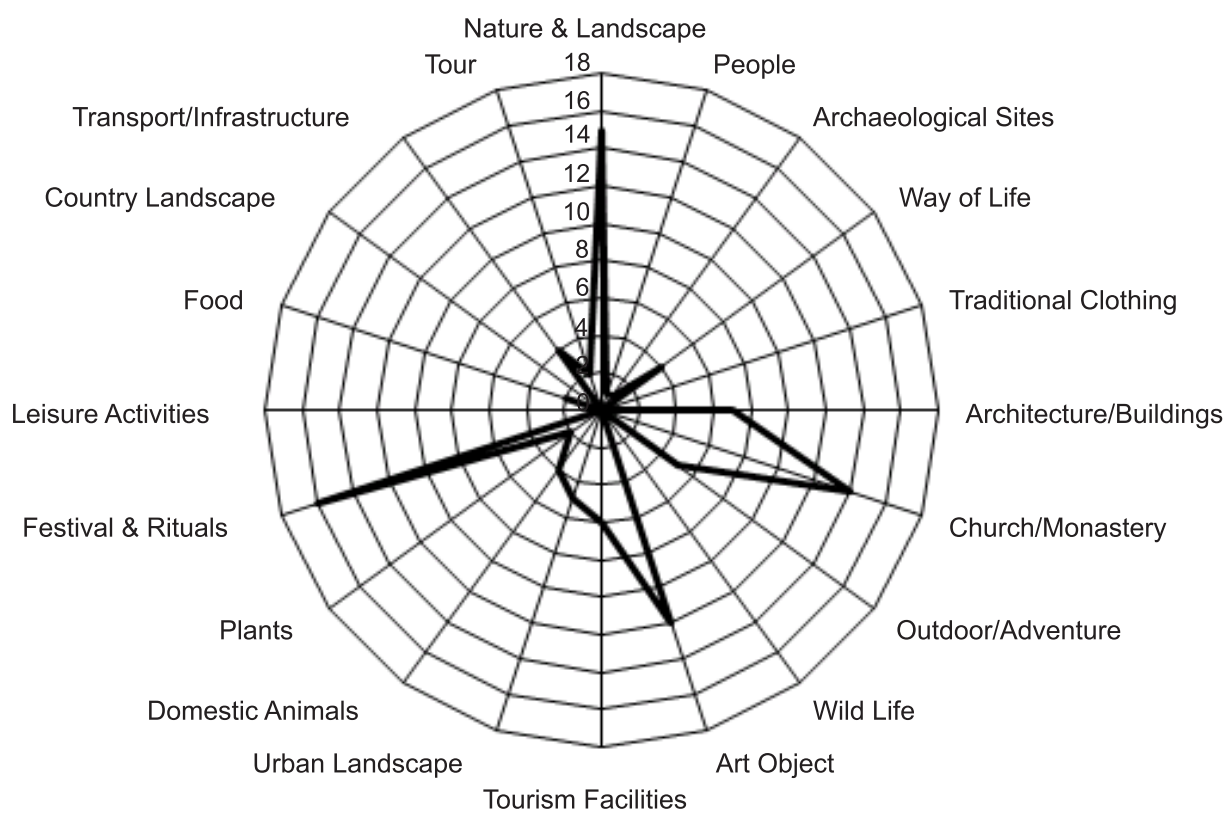

\section{Volga Federal District}

As in the CFD, the Volga Federal District DMOs' websites mainly focus on projecting pictures with Churches and Monasteries and Art Objects attributes. In contrast to other districts, a smaller portion of pictures are related to Leisure Activities that are offered at the destination. Interestingly, these leisure activities are mainly related to water sports and more adventurous sports activities such as ballooning. Also, leisure activities are often accompanied by nature and landscape attributes as the background motives of projected images (Figure 3 ). 


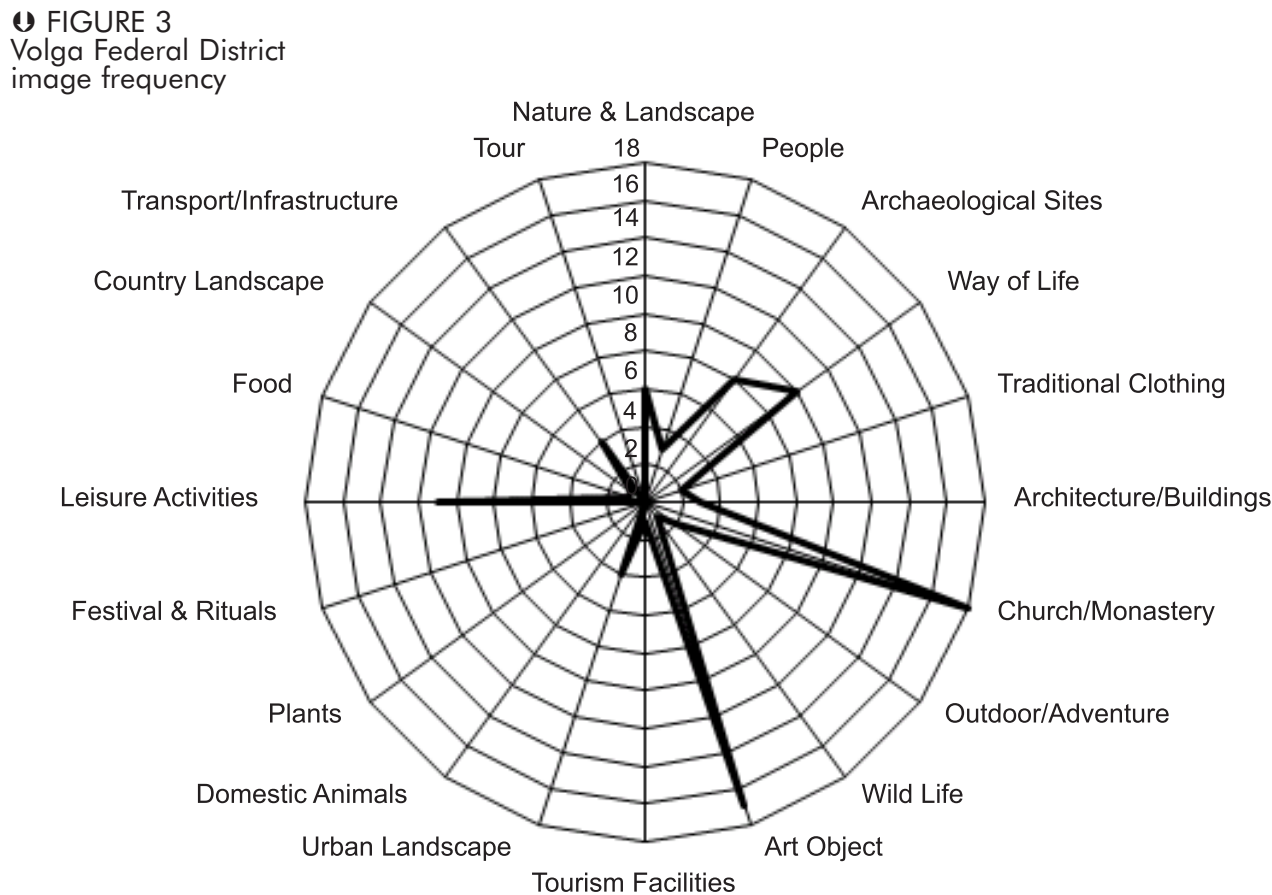

\section{Test of attribute independence: Chi-square analysis}

Chi-square test of independence was conducted to explore the relationships between thematically categorized attributes that comprised projected images across three examined districts (Appendix 1). All categories of attributes were independent, except the Festival and Rituals category (Chi square = 6.667; $p=0.036)$. Overall, the DMOs for all three samples featured mainly Art Object, Church/Monastery, and Architecture/Buildings destination attributes. This finding indicates a low level of pictorial diversity of DMO websites and lack of brand image uniqueness across examined districts. Interestingly, although the bear is the national symbol of Russia, wildlife does not appear as a frequent attribute on the DMO websites (see Appendix 1).

\section{The probability of attributes co-occurrence}

To calculate the probability of attributes co-occurrence, a total of 190 attribute pairs were tested, out of which 69 pairs $(36.32 \%)$ were removed from the analysis because expected co-occurrence was $<1$. This result suggests that most of the classifiable attribute pairs had 'truly random' associations (random $=113.0$ ). The significant non-random associations were mostly positive, particularly six were positive compared to two negative ones (Table 1). There were no unclassifiable attribute pairs. 
DRUŠ. ISTRAŽ. ZAGREB GOD. 27 (2018), BR. 4 STR. 735-755

ARMENSKI, T., STANKOV,

U., $\mathrm{CHOI}, \mathrm{H}-\mathrm{S}$.:

DESTINATION.

- TABLE 1

Co-occurrence summary

(1) TABLE 2

Significance levels for positive and negative co-occurrence patterns

\begin{tabular}{|c|c|c|c|c|c|c|c|c|c|c|}
\hline & $\begin{array}{l}\text { Sp1 } \\
\text { Name }\end{array}$ & $\begin{array}{l}\text { Sp2 } \\
\text { Name }\end{array}$ & $\begin{array}{l}\text { Sp1_- } \\
\text { Inc }\end{array}$ & $\begin{array}{l}\mathrm{Sp} 2 \\
\text { Inc }\end{array}$ & $\begin{array}{c}\text { Obs__} \\
\text { Cooccur }\end{array}$ & $\begin{array}{l}\text { Prob } \\
\text { Cooccur }\end{array}$ & $\underset{\text { Cooccur }}{\text { Exp_ }}$ & P_Lt & P_Gt & $\begin{array}{r}\text { Effect } \\
\text { size }\end{array}$ \\
\hline \multirow[t]{6}{*}{ Positive } & $\begin{array}{l}\text { Natural } \\
\text { Landscapes }\end{array}$ & $\begin{array}{l}\text { Domestic } \\
\text { Animals }\end{array}$ & 11 & 5 & 5 & 0.114 & 2.5 & 1.000 & 0.018 & 0.114 \\
\hline & $\begin{array}{l}\text { Way } \\
\text { of Life }\end{array}$ & $\begin{array}{l}\text { Churches and } \\
\text { Monasteries }\end{array}$ & 9 & 16 & 9 & 0.298 & 6.5 & 1.000 & 0.023 & 0.114 \\
\hline & $\begin{array}{l}\text { Festivals } \\
\text { \& Rituals }\end{array}$ & $\begin{array}{l}\text { Architecture/ } \\
\text { Buildings }\end{array}$ & 14 & 10 & 10 & 0.29 & 6.4 & 1.000 & 0.002 & 0.164 \\
\hline & $\begin{array}{l}\text { Churches and } \\
\text { Monasteries }\end{array}$ & $\begin{array}{l}\text { Art } \\
\text { Object }\end{array}$ & 16 & 14 & 13 & 0.463 & 10.2 & 0.999 & 0.011 & 0.127 \\
\hline & $\begin{array}{l}\text { Domestic } \\
\text { Animals }\end{array}$ & $\begin{array}{l}\text { Festivals \& } \\
\text { Rituals }\end{array}$ & 4 & 10 & 4 & 0.083 & 1.8 & 1.000 & 0.029 & 0.100 \\
\hline & $\begin{array}{l}\text { Urban } \\
\text { Landscape }\end{array}$ & $\begin{array}{l}\text { Transport/ } \\
\text { Infrastructure }\end{array}$ & 10 & 10 & 7 & 0.207 & 4.5 & 0.995 & 0.046 & 0.114 \\
\hline \multirow[t]{2}{*}{ Negative } & $\begin{array}{l}\text { Natural } \\
\text { Landscapes }\end{array}$ & $\begin{array}{l}\text { Tourism } \\
\text { Facilities }\end{array}$ & 11 & 5 & 5 & 0.114 & 2.5 & 1.000 & 0.018 & -0.113 \\
\hline & $\begin{array}{l}\text { Way } \\
\text { of Life }\end{array}$ & $\begin{array}{l}\text { Tourism } \\
\text { Facilities }\end{array}$ & 9 & 5 & 0 & 0.093 & 2.0 & 0.049 & 1.000 & -0.091 \\
\hline
\end{tabular}

Note: $\mathrm{sp} 1=$ Numeric label giving the identity of attribute 1 , assigned based on the order in the input matrix; $\mathrm{sp} 2=$ Numeric label for attribute 2; sp1_inc $=$ Number of websites that have attribute 1 ; sp2 inc $=$ Number of websites that have attribute 2; obs_cooccur $=$ Observed number of websites having both attributes; prob_cooccur $=$ Probability that both attributes occur at a website; exp_cooccur $=$ Expected number of websites having both attributes; $\mathrm{p}_{-} \mathrm{lt}=$ Probability that the two attributes would co-occur at a frequency less than the observed number of co-occurrence websites if the two attributes were distributed randomly (independently) of one another; $p_{\text {_gt }}=$ Probability of co-occurrence at a frequency greater than the observed frequency. Statistical significance: p_lt; p_gt $<0.1$ (90\% Confidence Interval (CI)); $<0.05(95 \%) ;<0.01(99 \%)$. 


\section{Text analysis: Induced image themes}

Regarding the websites text analysis, the CFD mainly uses toponyms and functional words, such as regions, tourists, visit and history. From the brand core-value words concerts emerged as dominant, by surprise, since little pictorial material from this district relates to Festivals and Rituals. In the NWFD, toponyms and functional worlds are also frequent ones. Novgorod is the most frequent word in the toponymic category, while "regions" and "tourism" are the most frequent functional worlds. The region of Volga is the only one where the brand core-value words such as festivals, cities, and craft, dominate.

(1) TABLE 3

Frequently used words in $\mathrm{DMO}$ web branding per district
Interestingly, no descriptive words were found on the DMO websites in the Volga region. Toponyms that present the main cities in the Volga region are also frequently used (Table 3).

\begin{tabular}{|c|c|c|c|c|c|c|c|c|c|c|c|c|}
\hline & \multicolumn{3}{|c|}{ Core-value words } & \multicolumn{3}{|c|}{ Descriptive words } & \multicolumn{3}{|l|}{ Toponyms } & \multicolumn{3}{|c|}{ Functional words } \\
\hline & Words & $\bmod$ & $\%$ & words & $\bmod$ & $\%$ & Words & $\bmod$ & $\%$ & words & mod & $\%$ \\
\hline \multirow[t]{7}{*}{ CFD } & Concert & 189 & 0.43 & ancient & 96 & 0.22 & Russian & 237 & 0.54 & region & 260 & 0.59 \\
\hline & Exhibition & 169 & 0.39 & famous & 83 & 0.19 & Ryazan & 198 & 0.45 & tourists & 240 & 0.55 \\
\hline & City & 153 & 0.35 & great & 83 & 0.19 & Moscow & 197 & 0.45 & visit & 190 & 0.43 \\
\hline & Theatre & 102 & 0.23 & folk & 75 & 0.17 & Yaroslavl & 129 & 0.29 & tour & 121 & 0.28 \\
\hline & Museum & 95 & 0.22 & & & & Oryol & 124 & 0.28 & history & 112 & 0.26 \\
\hline & Band & 84 & 0.19 & & & & Russia & 88 & 0.20 & tourism & 85 & 0.19 \\
\hline & & & & & & & Tambov & 75 & 0.17 & trip & 70 & 0.16 \\
\hline \multirow[t]{9}{*}{ NWFD } & City & 242 & 0.60 & ancient & 95 & 0.24 & Novgorod* & 238 & 0.59 & region & 387 & 0.96 \\
\hline & Museum & 145 & 0.36 & cultural & 91 & 0.23 & Russian & 216 & 0.54 & tourist & 192 & 0.48 \\
\hline & Church & 85 & 0.21 & unique & 80 & 0.20 & Arkhangelsk & 190 & 0.47 & tourism & 146 & 0.36 \\
\hline & Nature & 75 & 0.19 & northern & 73 & 0.18 & Petersburg & 149 & 0.37 & center & 128 & 0.32 \\
\hline & & & & & & & Karelia & 136 & 0.34 & century & 99 & 0.25 \\
\hline & & & & & & & Veliky & 133 & 0.33 & sights & 89 & 0.22 \\
\hline & & & & & & & Vologda & 132 & 0.33 & district & 88 & 0.22 \\
\hline & & & & & & & Pskov & 131 & 0.33 & & & \\
\hline & & & & & & & Russia & 128 & 0.32 & & & \\
\hline \multirow[t]{13}{*}{ VOLGA } & Festival & 72 & 0.45 & & & & Novgorod $^{* *}$ & 112 & 0.69 & region & 158 & 0.98 \\
\hline & City & 63 & 0.39 & & & & Nizhni & 64 & 0.40 & tourist & 47 & 0.29 \\
\hline & Crafts & 42 & 0.26 & & & & Kazan & 58 & 0.36 & history & 36 & 0.22 \\
\hline & Museum & 39 & 0.24 & & & & Mordovia & 58 & 0.36 & & & \\
\hline & Village & 39 & 0.24 & & & & Russia & 58 & 0.36 & & & \\
\hline & Culture & 37 & 0.23 & & & & Nizhny & 40 & 0.25 & & & \\
\hline & Events & 36 & 0.22 & & & & Russian & 39 & 0.24 & & & \\
\hline & People & 36 & 0.22 & & & & Tatarstan & 33 & 0.20 & & & \\
\hline & Art & 34 & 0.21 & & & & Volga & 31 & 0.19 & & & \\
\hline & Street & 34 & 0.21 & & & & & & & & & \\
\hline & Arts & 31 & 0.19 & & & & & & & & & \\
\hline & Nature & 31 & 0.19 & & & & & & & & & \\
\hline & Craft & 30 & 0.19 & & & & & & & & & \\
\hline
\end{tabular}

Note: * Novgorod Oblast or Veliky Novgorod city; ** Nizhny Novgorod Oblast or city. 
To reveal the elements of place branding, this study explores pictorial and textual content projected via official DMO websites of the Central Federal District, Northwestern Federal District and Volga Federal District, the most visited districts of the Russian Federation.

Although there was no evidence of significant differences between the examined districts in the web projected imagery, the frequency of pictorial attribute occurrences led to several conclusions. First, Art Object is the dominant attribute in the CFD and in the top five dominant attributes in the other two regions. Not surprisingly, since Moscow, the capital of the Russian Federation, has served as a cultural hub of the state throughout history, offering visitors a rich array of different art objects, museums and monuments representing various art forms.

Second, Churches and Monasteries, a representation of the spiritual life of the region, are the second most frequently used pictorial attributes in this district. Churches and Monasteries together with Art Objects are the only two attributes that ranked in the top five across all three examined regions. Russia is well known for its monumental churches and monasteries. The main symbol of Moscow, and entire Russia, is a picturesque church known as Saint Basil's Cathedral. With the dissolution of the Soviet Union, the Russian Orthodox Church as well as other religions and churches experienced a revival (Greeley, 1994), which has also been reflected in tourism branding of the districts. Interestingly, religious attributes emerged as the most frequent attributes in the VFD, which is the religiously most diverse district compared with the other two examined ones, with over $20 \%$ of the population practicing Islam; hence, Muslim religious and administrative units are present particularly in this diverse region. Besides Orthodox Christians and Muslims, due to the development of democratic social structures, different religious trends and ethical faiths, such as paganism and the old beliefs, experienced a rebirth (Volga Federal District official website, 2015).

Third, Festivals and Rituals are the most frequent attributes in the NWFD and in the top 5 attributes in the CFD, but they are underrepresented in the VFD. Accordingly, this is the only attribute that is statistically different from all 21 attributes across the examined districts. Like the Art Object category, one of the main reasons for its frequent occurrence could be the existence of the two most populated cities in Russia, Moscow and Saint Petersburg, both of which are tourism centers in the Russian Federation. The same could be applied to Architecture/Buildings, as one of the single most frequent attributes in the CFD and NWFD. 
DRUŠ. ISTRAŽ. ZAGREB GOD. 27 (2018), BR. 4,

ARMENSKI, T., STANKOV, U., $\mathrm{CHOI}, \mathrm{H}-\mathrm{S}$. DESTINATION. . STR. 735-755

Fourth, anthropogenic attributes are in the top five most frequently used attributes in all three regions, except in the NWFD were Natural Landscapes ranked second to Churches and Monasteries, Art Object, and Architecture/Buildings. However, knowing the SWFD's natural diversity based on relief forms, hydrology, and peculiarity of the northern pole position, this comes as no surprise.

Fifth, the VFD projects mainly attributes related to Leisure Activities \& Sport and Way of Life. This region is much more culturally diverse compared with others, and this could be one of the main reasons for the representation of those attributes. Representation of leisure activities and sports are the results of destination practitioners' effort to brand the city of Kazan as the "sports capital" of Russia, in the light of forthcoming mega sports events in Kazan (Golubchikov \& Slepukhina, 2014).

Supplementary word frequency analysis supported our findings of web projected image interpretation. For example, the brand-content related words "city" and "museum" that could visually represent image categories of Architecture/Buildings and Art Objects are the most frequently used words in all three districts. The word "nature" occurs most frequently in the NWFD, simultaneously accompanied by the pictorial material presenting natural landscapes, while "craft", "people", and "villages" most frequently appear in the VFD, where "Way of Life" is the focal web imagery.

Finally, the global overview of districts did not clearly show the distinction between web-projected imagery. This was confirmed by random co-occurrence of attributes analysis of the examined websites. This implies the absence of clear and unique branding strategies for the examined districts in European Russian.

This problem could be of a structural nature, lying in the organization of Russia's regionalization. According to Sergounin (2001), many Russian districts complained that the national administrative system does not consider their economic, cultural, and historical identities. For example, the Perm Region and Bashkortostan argued that economically, they are much closer to the Urals Federal District, though they were a part of the Volga Federal District.

\section{CONCLUSIONS}

With effective regional marketing, tourism could be one of the important mechanisms for generating positive associations with Russia. As noted by Andrades, Dimanche, and Ilkevich, (2015), international tourism has become an essential part of contemporary international relations. Modern Russia should 
DRUŠ. ISTRAŽ. ZAGREB GOD. 27 (2018), BR. 4 STR. 735-755

ARMENSKI, T., STANKOV, U., $\mathrm{CHOI}, \mathrm{H}-\mathrm{S}$.: DESTINATION.

\section{LIMITATIONS}

be characterized by a new qualitative state of a national economic, political, and social life (Bagautdinova, Gafurov, Kalenskaya, \& Novenkova, 2012). It is becoming a significant part of the world's growing economic integration and globalization processes. This questions the country's competitiveness.

Having a clear and comprehensive idea of visual communication is a prerequisite for defining branding strategies and an integrative marketing plan for territorial development that should be the result of cooperation between the different destination marketing organizations (DMO) and policy makers (Bagautdinova et al., 2012; Morozova, Morozov, Havanova, Litvinova, \& Bokareva, 2016). Specifically, synchronized effort and greater cooperation between tourism businesses, governments, and non-profit organizations are required to align brand messages and to position the DMOs to communicate a strong and distinguished tourism brand for their districts (Mariani, Buhalis, Longhi, \& Vitouladiti, 2014; Yashalova et al., 2017). However, many academics and practitioners have noticed that brand 'Russia' apparently lacks a solid national idea and brand identity that should be communicated via DMO websites (Andrades et al., 2015).

Hence, it is crucial to find a compromise between Russian branding and visual communication in a way to effectively promote the country on the international tourism market. It is also a central concern for this country to work toward favorable place brand imaging that diverges from the national brand. In many cases, as noted by Dinnie (2008), too tight a link between tourism and the nation-brand, for example, may prove unfavorable, particularly for countries whose tourism industry is founded upon rural and traditional imagery such as in European Russia. This study adds to the knowledge of place branding communication through the DMO websites of European Russia.

This study has some important limitations. Like in any other similar endeavor, this study measured the projected images only at one period. Seasons or other vacation periods could bias the results. For example, content analysis of the DMOs' websites was conducted in March, a low season, which could lead to Festivals and Rituals being omitted from the projected pictures of the Volga Federal District. The content text analysis, however, shows that brand-related words such as "festival" and "event" are present on the website of this district. Hence, the absence of "Festivals and Rituals" category for the VFD is related to the intentional branding choice of the DMO web imagery rather than the real absence of these activities. 
DRUŠ. ISTRAŽ. ZAGREB GOD. 27 (2018), BR. 4 STR. 735-755

ARMENSKI, T., STANKOV, U., $\mathrm{CHOI}, \mathrm{H}-\mathrm{S}$. DESTINATION...
This study could not represent the entire European Russia but has geographically covered only three districts. Also, the study focused solely on the districts' official DMO websites, excluding other tourism portals of different cities or areas. Finally, due to the lack of English versions of the official district DMO web pages, the South Federal District was dropped from the analysis, although it provides significant tourism resources visited mostly by domestic tourists. For example, Krasnodar Krai, as a federal subject in the Southern Federal District where Sochi is located, does not have an English version of the DMO website. Meanwhile, with the Winter Olympics in 2014 and the 2018 FIFA World Cup, Sochi intends to be a showcase of the "re-emerging" Russian State for the global audience (Golubchikov \& Slepukhina, 2014). In conclusion, this exploratory study is just the first step in the web brand analysis, and future studies will have to fill in the missing pieces of the puzzle by assembling the tourism branding mosaic of European Russia.

\section{APPENDIX}

\section{Attribute counts: Chi-square test of independence}

\begin{tabular}{lrrrc}
\hline Categories & $\begin{array}{c}\text { Central } \\
\text { Federal District }\end{array}$ & $\begin{array}{c}\text { Northwestern } \\
\text { Federal District }\end{array}$ & $\begin{array}{c}\text { Volga } \\
\text { Federal District }\end{array}$ & Chi-Square \\
\hline Natural Landscapes & 13 & 15 & 6 & 0.209 \\
People & 1 & 1 & 3 & 1.459 \\
Archaeological Sites & 1 & 1 & 8 & 0.138 \\
Way of Life & 6 & 4 & 10 & 0.631 \\
Traditional Clothing & 3 & 0 & 2 & 2.022 \\
Architecture/Buildings & 17 & 7 & 3 & $5.325^{*}$ \\
Churches and Monasteries & 30 & 14 & 18 & 0.886 \\
Outdoor/Adventure & 4 & 5 & 2 & 2.081 \\
Wild Life & 0 & 0 & 1 & 2.667 \\
Art Object & 40 & 12 & 17 & 2.944 \\
Tourism Facilities & 6 & 6 & 1 & 1.249 \\
Urban Landscape & 5 & 5 & 4 & 0.056 \\
Domestic Animals & 2 & 4 & 0 & 2.761 \\
Plants & 13 & 2 & 0 & 3.460 \\
Festivals \& Rituals & 19 & 16 & 0 & $6.667^{* * *}$ \\
Leisure Activities and Sport & 3 & 0 & 11 & $4.861^{*}$ \\
Food & 1 & 2 & 1 & 0.413 \\
Country Landscape & 3 & 0 & 1 & 2.144 \\
Transport/Infrastructure & 5 & 4 & 4 & 0.177 \\
Tour & 1 & 2 & 0 & 0.792 \\
\hline & & & & \\
\hline
\end{tabular}


Almeyda-Ibáñez, M., \& George, B. P. (2017). The evolution of destination branding: A review of branding literature in tourism. Journal of Tourism, Heritage \& Services Marketing, 3(1), 9-17. https://doi.org/10. 5281/zenodo.401370

Andrades, L., Dimanche, F., \& Ilkevich, S. (2015). Tourist behaviour and trends. In F. Dimanche, \& L. Andrades (Eds.), Tourism in Russia: A management handbook (pp. 101-130). Bingley, West Yorkshire: Emerald Publishing.

Anholt, S. (2005). Nation Brand Index: How does the world see America? Journal of Advertising Research, 45(3), 296-304.

Anholt, S. (2008). Place branding: Is it marketing, or isn't it? Place Branding and Public Diplomacy, 4(1), 1-6.

Anholt, S. (2009). Editorial: Should place brands be simple? Place Branding and Public Diplomacy, 5(2), 91-96.

Bagautdinova, N., Gafurov, I., Kalenskaya, N., \& Novenkova, A. (2012). The regional development strategy based on territorial marketing (the case of Russia). World Applied Sciences Journal, 18(18), 179-184.

Balakrishnan, S. M., Nekhili, R., \& Lewis, C. (2011). Destination brand components. International Journal of Culture, Tourism and Hospitality Research, 5(1), 4-25. https://doi.org/10.1108/17506181111111726

Bharanipriya, V., \& Prasad, V. K. (2011). Web content mining tools: A comparative study. International Journal of Information Technology and Knowledge Management, 4(1), 211-215.

Blain, C., Levy, S. E., \& Ritchie, J. R. B. (2005). Destination branding: Insights and practices from destination management organizations. Journal of Travel Research, 43(4), 328-338. https://doi.org/10.1177/0047 287505274646

Cai, L. A. (2002). Cooperative branding for rural destinations. Annals of Tourism Research, 29(3), 720-742. https://doi.org/10.1016/S0160-7383 (01)00080-9

Choi, S., Lehto, X. Y., \& Morrison, A. M. (2007). Destination image representation on the web: Content analysis of Macau travel related websites. Tourism Management, 28(1), 118-129. https://doi.org/10.1016/ j.tourman.2006.03.002

Dinnie, K. (2008). Nation branding and Russia: Prospects and pitfalls. Russian Journal of Communication, 1(2), 199-201.

Faizova, G., Kozhevnikova, N., Kashipova, G., Zinurova, G., \& Egorov, E. (2015). Factors of functioning and development of tourist clusters at regional level. European Research Studies Journal, 18(3), 91-102.

Fan, Y. (2006). Branding the nation: What is being branded? Journal of Vacation Marketing, 12(1), 5-14. https://doi.org/10.1177/1356766706056633

Gnoth, J. (2002). Leveraging export brands through a tourism destination brand. Journal of Brand Management, 9(4), 262-280. https://doi. org/10.1057/palgrave.bm.2540077

Golubchikov, O., \& Slepukhina, I. (2014). Russia - showcasing a 're-emerging' state? In J. Grix (Ed.), Leveraging legacies from sports mega- 
DRUŠ. ISTRAŽ. ZAGREB GOD. 27 (2018), BR. 4,

ARMENSKI, T., STANKOV, $\mathrm{U}$. $\mathrm{CHOI}, \mathrm{H}-\mathrm{S}$. DESTINATION.. STR. 735-755

events. Concepts and cases (pp. 166-177). Palgrave Macmillan, UK: Springer Link.

Gonzalez, A. M., \& Bello, L. (2002). The construct "lifestyle" in market segmentation: The behavior of tourist consumers. European Journal of Marketing, 36(1/2), 51-85. https://doi.org/10.1108/03090560210412700

Govers, R., \& Go, F. (2016). Place branding: Global, virtual and physical identities, constructed, imagined and experienced. New York: Springer.

Govers, R., \& Go, F. (2009). Place branding - Global, physical and virtual identities constructed, imagined or experienced. New York: Palgrave Macmillan.

Govers, R., \& Go, F. M. (2004). Projected destination image online: Website content analysis of pictures and text. Information Technology E Tourism, 7(2), 73-89. https://doi.org/10.3727/1098305054517327

Greeley, A. (1994). Religion's revival in the former communist empire: Religion in Russia simply became dormant under communism. Available at https://ropercenter.cornell.edu/public-perspective/ppscan/53/53019.pdf

Griffith, M. D., Veech, A. J., \& March, J. C. (2016). Co-occur: Probabilistic species co-occurrence analysis in R. Journal of Statistical Software, 69(2), 1-17.

Hankinson, G. (2009). Managing destination brands: Establishing a theoretical foundation. Journal of Marketing Management, 25(1-2), 97-115. https://doi.org/10.1362/026725709X410052

Istomina, T. S., \& Samoilenko, A. A. (2015). Tourism in Russia - Strength Test. Resorts Services in Tourism, 1(26), 28-31.

Ivanov, I. (2001). The new Russian identity: Innovation and continuity in Russian foreign policy. The Washington Quarterly, 24(3), 5-13. https://doi.org/10.1162/01636600152102160

Kolbe, H. R., \& Burnett, S. M. (1991). Content-analysis research: An examination of applications with directives for improving research reliability and objectivity. Journal of Consumer Research, 18(2), 243-250. https://doi.org/10.1086/209256

Költringer, C., \& Dickinger, A. (2015). Analyzing destination branding and image from online sources: A web content mining approach Journal of Business Research, 68(9), 1836-1843. https://doi.org/10.1016/j. jbusres.2015.01.011

Krivosheeva, T., Kopylov, Y., \& Tatiana, K. (2015). The demand characteristics of tourism products consumption in the Moscow Region. Tourism in transition economies - Issues and challenges for destination competitiveness. September, Caceres, Spain, pp. 103-107.

Liu, B. (2007). Web data mining: Exploring hyperlinks, contents, and usage data. Berlin: Springer Science \& Business Media.

Mariani, M. M., Buhalis, D., Longhi, C., \& Vitouladiti, O. (2014). Managing change in tourism destinations: Key issues and current trends. Journal of Destination Marketing \& Management, 2(4), 269-272. https://doi. org/10.1016/j.jdmm.2013.11.003

Morozova, M., Morozov, V., Havanova, N., Litvinova, E., \& Bokareva, 
DRUŠ. ISTRAŽ. ZAGREB GOD. 27 (2018), BR. 4 STR. $735-755$

ARMENSKI, T., STANKOV $\mathrm{U}$. $\mathrm{CHOI}, \mathrm{H}-\mathrm{S}$ : DESTINATION. .
Russian Federation, with account of the tourism infrastructure factors. Indian Journal of Science and Technology, 9(5), 1-13.

Nikolaeva, J. V., Bogoliubova, N. M., \& Shirin, S. S. (2018). Ecological tourism in the state image policy structure. Experience and problems of modern Russia. Current Issues in Tourism, 21(5), 547-566. https://doi. org $/ 10.1080 / 13683500.2015 .1100588$

Qu, H., Kim, L. H., \& Im, H. H. (2011). A model of destination branding: Integrating the concepts of the branding and destination image. Tourism Management, 32(3), 465-476. https://doi.org/10.1016/j.tourman. 2010.03.014

Roberts, H. G. (2014). Message on a bottle: Packaging the Great Russian past. Consumption Markets \& Culture, 17(3), 295-313. https://doi.org/ 10.1080/10253866.2013.791973

Saunders, R. A. (2016). Popular geopolitics and nation branding in the Post-Soviet realm. London: Routledge. https://doi.org/10.4324/9781315 737386

Sergounin, A. (2001). Russia's regionalization: The interplay of domestic and international factors. In A. Aldis, \& G. P. Herd (Eds.), Russian regions and regionalism. Strength through weakness (pp. 101-119). London and New York, Routledge Curzon.

Simons, G. (2011). Attempting to re-brand the branded: Russia's international image in the 21st century. Russian Journal of Communication, 4(3-4), 322-350. https://doi.org/10.1080/19409419.2011.10756816

Stepchenkova, S., \& Morrison, A. M. (2006). The destination image of Russia: From the online induced perspective. Tourism Management, 27(5), 943-956. https://doi.org/10.1016/j.tourman.2005.10.021

Stepchenkova, S., \& Morrison, A. M. (2008). Russia's destination image among American pleasure travelers: Revisiting Echtner and Ritchie. Tourism Management, 29(3), 548-560. https://doi.org/10.1016/ j.tourman.2007.06.003

Stepchenkova, S., Kirilenko, A. P., \& Morrison, A. M. (2009). Facilitating content analysis in tourism research. Journal of Travel Research, 47(4), 454-469. https://doi.org/10.1177/0047287508326509

Stepchenkova, S., \& Zhan, F. (2013). Visual destination images of Peru: Comparative content analysis of DMO and user-generated photography. Tourism Management, 36, 590-601. https://doi.org/10.1016/j.tourman. 2012.08.006

Yashalova, N. N., Akimova, M. A., Ruban, D. A., Boyko, S. V., Usova, A. V., \& Mustafayeva, E. R. (2017). Prospects for the regional development of industrial tourism in the light of the analysis of main economic indicators in the Russian tourism industry. Economic and Social Changes: Facts, Trends, Forecast, 10(2), 195-213. 
DRUŠ. ISTRAŽ. ZAGREB GOD. 27 (2018), BR. 4 STR. 735-755

ARMENSKI, T., STANKOV, $\mathrm{U}$. $\mathrm{CHOI}, \mathrm{H}-\mathrm{S}$. DESTINATION..

\section{Brendiranje Europske Rusije kao turističke destinacije: empirijsko istraživanje slika projiciranih na internetu}

Tanja ARMENSKI, Uglieša STANKOV

Prirodoslovno-matematički fakultet, Sveučilište u Novom Sadu, Novi Sad

Hwan-Suk CHOI

Škola za ugostiteljstvo, hranu i turistički menadžment, Sveučilište Guelph, Guelph, ON, Kanada

Online brendiranje važan je strateški alat u izgradnji kvalitetnog iskustva turističkoga putovanja, koje je jedinstveno povezano s odredištem i koje jača emocionalnu vezu između posjetitelja i mjesta. Širenjem interneta, web-stranice organizacija za destinacijski menadžment (DMO) postale su ključni komunikacijski kanal za prikazivanje poželine brendirane slike mjesta. U pokušaju rehabilitacije brendirane slike Rusije, ova studija istražuje: (1) koji su dominantni atributi u brendiranim slikama Europske Rusije koje se prenose putem DMO web-stranica; (2) koje se riječi najčešće pojavljuju na DMO internetskim stranicama Europske Rusije; (3) postoji li nepodudarnost između projiciranih brendiranih slika i priča koje se prenose tekstom na DMO web-stranicama. Budući da ova pitanja pridonose boljem razumijevanju inducirane komponente ruske brendirane slike mjesta $u$ online okruženju, provedena je analiza sadržaja DMO web-stranica triju oblasti Europske Rusije uz raspravu o praktičnim implikacijama. Rezultati su posebno važni za područje marketinga.

Ključne riječi: brendiranje mjesta, brendirane slike, DMO web-stranice, Europska Rusija

\section{(c) (1) (3)}

Međunarodna licenca / International License:

Imenovanje-Nekomerciijalno / Attribution-NonCommercial 